\title{
REVIEW
}

\section{Translational Medicine in Fish-derived Peptides: From Fish Endocrinology to Human Physiology and Diseases}

\author{
KAZUHIRO TAKAHASHI
}

Department of Molecular Biology and Applied Physiology, Tohoku University School of Medicine, 2-1 Seiryo-machi, Aoba-ku, Sendai, Miyagi 980-8575, Japan

\begin{abstract}
Recent studies have revealed the importance of fish-derived peptide hormones to human endocrinology. These peptides include melanin-concentrating hormone $(\mathrm{MCH})$, urocortins (human urotensin-I), and urotensin-II. MCH, a hypothalamic peptide, is a potent stimulator on appetite. Urocortins, e.g. urocortin 1 and urocortin 3 (stresscopin), are endogenous ligands for the corticotropin-releasing factor (CRF) receptors, particularly CRF type 2 receptor, that mediates a vasodilator action, a positive inotropic action and a central appetite-inhibiting action. These actions mediated by CRF type 2 receptor may ameliorate the stress response. Human urotensin-II is a potent vasoconstrictor peptide, while it acts as a vasodilator on some arteries. Human urotensin-II is expressed in various types of cells and tissues, including cardiovascular tissues, as well as many types of tumor cells. Thus, these fish-derived peptides appear to play important roles in human physiology, such as appetite regulation, stress response and cardiovascular regulation, and also in diseases, for example, obesity, cardiovascular diseases and tumors. Development of antagonists/agonists against the receptors for these peptides may open new strategies for the treatment of various diseases, including obesity-related diseases, hypertension, heart failure and malignant tumors.
\end{abstract}

Key words: Melanin-concentrating hormone, Urotensin, Urocortin, Neuropeptide, Cardiovascular

(Endocrine Journal 51: 1-17, 2004)

IN the last century, a large number of peptide hormones were discovered. Some of the novel peptides are produced and secreted by classically non-endocrine organs, such as brain, heart and vascular vessels [1], while some were originally discovered in non-mammalian species including fishes.

The peptides produced by classically non-endocrine organs include hypothalamic hormones and various neuropeptides secreted by neurons [2-5], atrial natriuretic peptide (ANP) and B-type natriuretic peptide (BNP) by heart [6] and endothelins by vascular endothelium [7]. Some peptides appear to be ubiquitously expressed. For example, adrenomedullin, a vasodilator peptide discovered from pheochromocytoma tissue, is produced and secreted by various types of

Correspondence to: Kazuhiro TAKAHASHI, M.D., Department of Molecular Biology and Applied Physiology, Tohoku University School of Medicine, 2-1 Seiryo-machi, Aoba-ku, Sendai, Miyagi 980-8575, Japan normal cells $[1,8,9,10]$, such as fibroblasts [10], macrophages [10, 11], glial cells [12] and retinal pigment epithelial cells $[13,14]$, and by various tumor cells $[1,15-19]$. Endothelin-1 is also ubiquitously expressed like adrenomedullin although it was originally isolated from aortic endothelial cells [7, 20,21]. Thus, a large number of studies on hormones now aim not only at classical endocrine organs, but also at nonendocrine organs, such as cardiovascular organs.

Another important aspect of the recent advances in peptide endocrinology is recognition of the importance of fish-derived hormones in human physiology and diseases. In this review, I will discuss three bioactive peptides: melanin-concentrating hormone $(\mathrm{MCH})$ [22], urotensin-I $[23,24]$ and urotensin-II $[25,26]$. These three peptides were originally discovered in fishes, and are now recognized to have very important physiological roles in mammals including human. Furthermore, receptors for these peptides are targets for the discovery of novel drugs for human diseases, such as cardio- 
vascular disease and obesity.

\section{Melanin-concentrating hormone (MCH)}

A dual hormonal control of color change by two antagonistic pituitary melanophorotropic hormones was first postulated in amphibia by Hogben and Slome in 1931 [27]. $\alpha$-Melanocyte-stimulating hormone $(\alpha-\mathrm{MSH})$ and $\beta-\mathrm{MSH}$ are responsible for pigment dispersion in the integumentary melanopore of lower vertebrates. $\mathrm{MCH}$ is a 17 amino acid peptide originally isolated from chum salmon pituitaries by Kawauchi et al. [22] (Table 1). In contrast to $\alpha$ - and $\beta$-MSH, $\mathrm{MCH}$ induces melanosome aggregation within melanophores of teleost fish, and makes the skin color of fishes pallor.

$\mathrm{MCH}$ is present in the neurons of lateral basal hypothalamus of fishes such as the teleost fishes, trout and carp $[28,29]$ and $\mathrm{MCH}$ immunoreactive axons projected into the brain and pituitary. $\mathrm{MCH}$ is a circulating hormone in fishes and plasma $\mathrm{MCH}$ concentrations were increased by stress and when placed on a white background [30-33]. Salmon MCH is a potent inhibitor of CRF-induced secretion of $\alpha-\mathrm{MSH}$ and $\mathrm{ACTH}$ in vitro by teleost pituitary glands $[34,35] . \mathrm{MCH}$ may play important roles in skin pigmentation and in certain aspects of the stress response in fishes.

Subsequent studies have shown the presence of $\mathrm{MCH}$ in mammals including human. Rat $\mathrm{MCH}$ was isolated from rat hypothalamus [36] and the cDNAs encoding $\mathrm{MCH}$ precursor have been cloned from a rat hypothalamic cDNA library [37]. The amino acid sequence of human $\mathrm{MCH}$ was predicted by the cDNA cloning using a human hypothalamic cDNA library [38]. Human $\mathrm{MCH}$, a 19 amino acid peptide, is identical to rat $\mathrm{MCH}$, but differs from salmon $\mathrm{MCH}$ by an $\mathrm{N}$-terminal extension of two amino acids and four additional substitutions (Table 1). Immunocytochemistry and in situ hybridization in the rat brain showed that $\mathrm{MCH}$ neurons were mostly present in the lateral hypo- thalamic area, with smaller cell groups found in the olfactory tubercle and pontine tegmentum [39-41]. $\mathrm{MCH}$ is also expressed in human hypothalamus, mostly posterior and lateral hypothalamic areas (Fig. 1), including perifornical nucleus, tuberomammillary nucleus, and posterior nucleus of hypothalamus [42-44]. The distribution of $\mathrm{MCH}$ immunoreactive cell bodies is similar to that in other mammals. Immunoreactive$\mathrm{MCH}$ was detected in the extrahypothalamic brain regions [44, 45], but $\mathrm{MCH}$ mRNA was detected only in the hypothalamus by Northern blot analysis [46] (Fig. 1, 2), suggesting that immunoreactive-MCH in the extrahypothalamic brain regions may be due to the immunoreactive- $\mathrm{MCH}$ in the nerve fibers originated from the hypothalamic nuclei as mentioned above.

$\mathrm{MCH}$ has been shown to have important physiological roles in the central appetite regulation in mammals $[47,48]$. MCH is one of the most potent stimulators of feeding and may be a target molecule for leptin, that is secreted by adipocytes and suppresses appetite. Differential display polymerase chain reaction showed overexpression of $\mathrm{MCH}$ in the hypothalamus of $o b / o b$ obese mice, that genetically lack bioactive leptin [47]. Fasting further increased expression of MCH mRNA in both normal and obese animals. Intracerebroventricular injection of $\mathrm{MCH}$ increased food consumption. These findings suggest that $\mathrm{MCH}$ participates in the hypothalamic regulation of body weight. Moreover, $\mathrm{MCH}-$ deficient mice have reduced body weight and leanness due to hypophagia (reduced feeding) and an inappropriately increased metabolic rate, whereas plasma leptin levels were decreased and pro-opiomelanocortin mRNA expression levels in arcuate nucleus were suppressed [48].

In addition to appetite-stimulating effects, various biological actions of $\mathrm{MCH}$ in the brain and pituitary have been demonstrated in mammals. $\mathrm{MCH}$ inhibited pentylenetetrazole-induced seizure $[49,50] . \mathrm{MCH}$ modulated ACTH secretion, probably via corticotropin-releasing factor (CRF) release [51]. On the other hand, Navarra et al. reported that rat $\mathrm{MCH}$ did not

Table 1. Amino acid sequences of salmon melanin-concentrating hormone (MCH) and human/rat $\mathrm{MCH}$

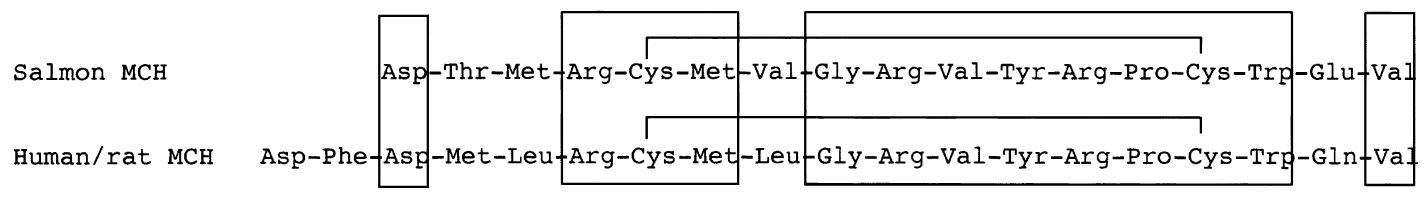

Amino acids commonly found in salmon and human/rat $\mathrm{MCH}$ are shown by square. 

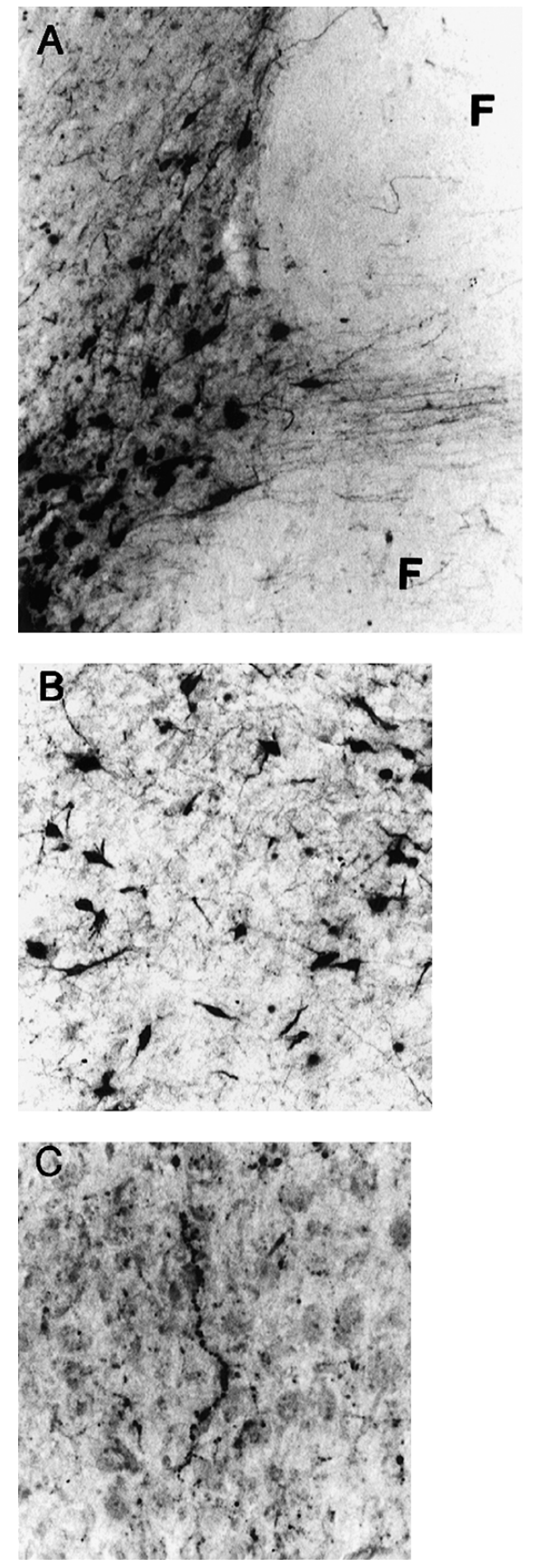

Fig. 1. Immunocytochemistry of melanin-concentrating hormone $(\mathrm{MCH})$ in the human hypothalamus. (A) Perifornical nucleus $(\times 100)$. F; fornix. (B) Tuberomammillary nucleus $(\times 100)$. (C) $\mathrm{MCH}$ positive nerve fiber in the periventricular area $(\times 250)$. Reproduced from ref [44] Mouri et al. Peptides 14: 643-646; 1993 with kind permission from Elsevier Science.

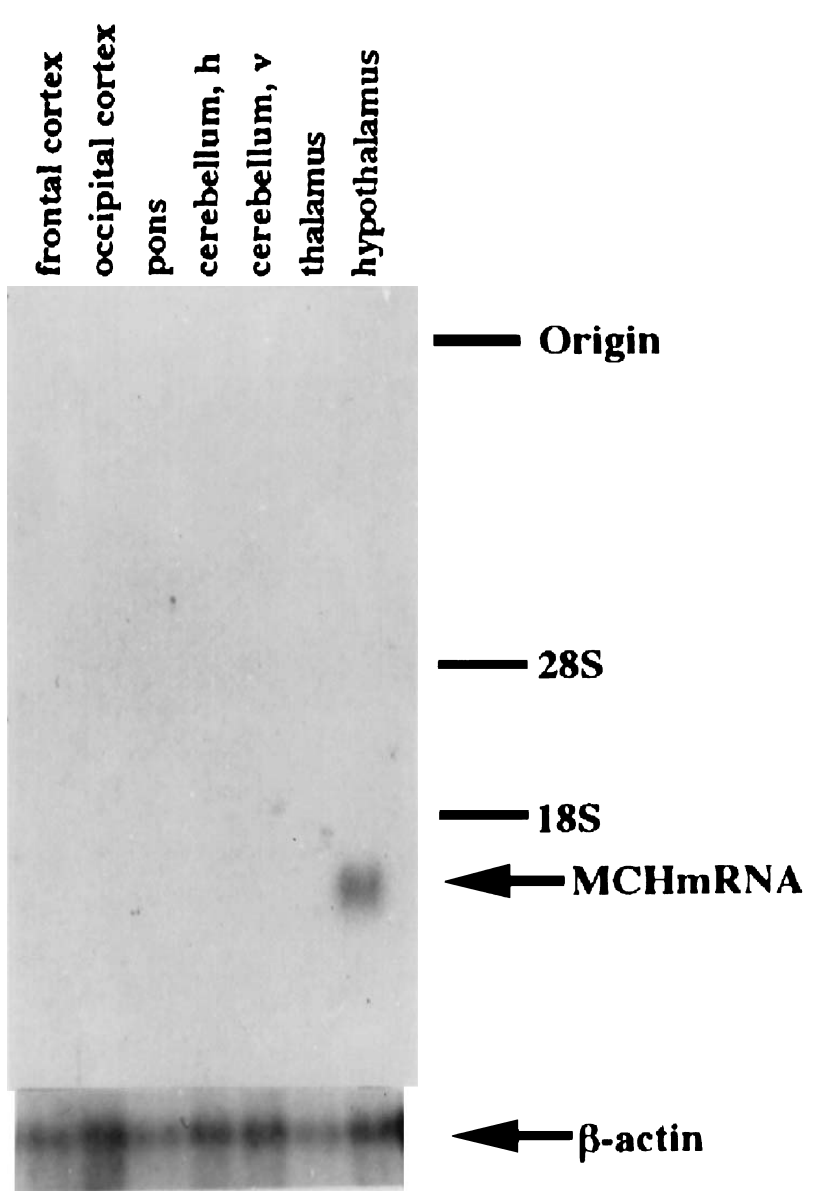

Fig. 2. Northern blot analysis of melanin-concentrating hormone $(\mathrm{MCH})$ mRNA in human brain. Each lane contained $15 \mu \mathrm{g}$ total RNA. The bottom panel shows the expression of $\beta$-actin mRNA. Cerebellum, $\mathrm{h}=$ cerebellar hemisphere; cerebellum, $\mathrm{v}=$ cerebellar vermis. Reproduced from ref [46] Takahashi et al. Neuroendocrinology 61: 493-498; 1995 with kind permission from S. Karger AG.

affect the release of CRF from the rat hypothalamus or $\mathrm{ACTH}$ from the anterior pituitary in vitro [52]. $\mathrm{MCH}$ stimulated release of luteinizing hormone-releasing hormone (LH-RH) and gonadotropins from the hypothalamo-pituitary axis [53, 54]. Furthermore, $\mathrm{MCH}$ stimulated sexual behavior, when injected into the medial preoptic area and the ventromedial nucleus [55]. On the other hand, it was reported that intracerebroventricular administration of $\mathrm{MCH}$ suppressed pulsatile LH release in the female rat [56]. This inconsistency may be due to the difference of experimental conditions, such as injection sites in the brain, presence or absence of estrogen treatment and sampling conditions. $\mathrm{MCH}$ inhibited the thyroid axis via the 
suppression of TSH release [57]. Central administration of $\mathrm{MCH}$ also had effects on behavior in rats. For example, $\mathrm{MCH}$ had an anxiogenic effect when injected into the medial preoptic area [55]. $\mathrm{MCH}$ modulated memory retention by acting on the amygdala and hippocampus [58]. Most of these biological actions of $\mathrm{MCH}$ are mediated by an opposite mechanism of action compared with those of $\alpha-\mathrm{MSH}$.

Thus, $\mathrm{MCH}$ acts primarily as a neurotransmitter or a neuromodulator in mammals, whereas $\mathrm{MCH}$ is a circulating hormone in fishes. It has recently been shown, however, that $\mathrm{MCH}$ has biological effects on the peripheral tissues, and that $\mathrm{MCH}-$ like immunoreactivity is present in rat plasma. Bradley et al. reported that $\mathrm{MCH}$ stimulated leptin mRNA expression and leptin secretion in isolated rat adipocytes [59]. $\mathrm{MCH}$ activated signaling pathways, such as p44/42 MAPK and pp70 S6 kinase activities, in 3T3-L1 adipocytes [60]. In our previous studies, immunoreactive-MCH was not detected in human plasma $(<0.25 \mathrm{fmol} / \mathrm{ml})$ [46] or in rat plasma (our unpublished observations), whereas Bradley et al. [59] and Stricker-Krongrad et al. [61] have suggested the presence of MCH-like immunoreactivity in rat plasma. Bradley et al. reported that rat plasma levels of $\mathrm{MCH}$ or $\mathrm{MCH}$-like peptide, measured by a commercially available RIA kit (Phoenix Pharmaceuticals, Mountain View, CA), ranged between 54 and $397 \mathrm{pg} / \mathrm{ml}$ [59]. Stricker-Krongrad et al. reported that plasma concentrations of MCH-like immunoreactivity, measured by a commercially available competitive enzyme immunoassay kit (Phoenix Pharmaceuticals, Mountain View, CA), were $65.9 \pm 3.2 \mathrm{ng} / \mathrm{ml}$ (mean \pm SEM) in obese fa/fa Zucker rats and $1.7 \pm 0.1$ $\mathrm{ng} / \mathrm{ml}$ in lean homozygous Zucker rats [61]. Surprisingly, these levels were about 1000 times higher than the detection limit of our plasma $\mathrm{MCH}$ assay. In the study by Stricker-Krongrad et al. [61], plasma samples were measured without extraction using the commercially available kit. Therefore there is the possibility that proteins in unextracted plasma had nonspecific effects on the assays. Chromatographic characterization of $\mathrm{MCH}$-like immunoreactivity in plasma has not been presented by these groups or by others.

There are at least two isoforms of $\mathrm{MCH}$ receptors, $\mathrm{MCH}$ receptor 1 and $\mathrm{MCH}$ receptor 2, which are distinct from melanocortin receptors. Five independent groups reported that the orphan G-protein-coupled receptor, SLC-1, is the $\mathrm{MCH}$-specific receptor almost at the same time [62-66]. SLC-1 is now called MCH receptor 1. The pathway mediated by this $\mathrm{MCH}$ receptor 1 was activated by $\mathrm{MCH}$ at $\mathrm{nM}$ concentrations, but not by $\alpha-\mathrm{MSH}$. Consistent with these findings, $\mathrm{MCH}$ did not block $\alpha$-MSH binding or $\alpha-\mathrm{MSH}-$ induced cAMP accumulation in cells expressing either the melanocortin 3 or melanocortin 4 receptor [67].

$\mathrm{MCH}$ receptor $1 \mathrm{mRNA}$ is expressed not only in brain tissues, but also in peripheral tissues, such as adrenal glands, tumor tissues of pheochromocytomas and neuroblastomas, and various human tumor cell lines [68]. Subsequently, another isoform of the $\mathrm{MCH}$ receptor, $\mathrm{MCH}$ receptor 2, has been identified by several groups almost at the same time [69-74]. MCH receptor 2 is also a G-protein-coupled receptor with 7 transmembrane domains, and shows $38 \%$ identity to $\mathrm{MCH}$ receptor 1. Both $\mathrm{MCH}$ receptor 1 and 2 are expressed predominantly in the brain, consistent with the presence of MCH binding sites in the brain tissues [75]. Although the distribution of these two receptors are similar, higher relative levels of $\mathrm{MCH}$ receptor 1 were found in the pituitary, hypothalamus, locus ceruleus, medulla oblongata and cerebellum. $\mathrm{MCH}$ receptor 2 is also expressed in the peripheral tissues, such as the intestines, lymphocytes, adipose tissue and prostate gland, at lower levels than the brain [70]. Targeted disruption of the $\mathrm{MCH}$ receptor 1 results in hyperphagia and resistance to diet-induced obesity [76, 77]. This may suggest that the MCH signaling in the brain is related not only to appetite stimulation, but also to the central control of energy metabolism. Further studies are also required to clarify whether $\mathrm{MCH}$ receptor 2 signalling is increased in the $\mathrm{MCH}$ receptor 1 gene knockout mice.

Obesity is related to higher incidence of diabetes, hyperlipidemia and cardiovascular disease, such as hypertension and coronary artery diseases, and is therefore one of the greatest problems in health and medical care in developed countries. The $\mathrm{MCH}$ receptors are now regarded as an important target for novel drugs against obesity. Several types of $\mathrm{MCH}$ receptor 1 antagonists have been reported [78-80]. Interestingly, one antagonist for the $\mathrm{MCH}$ receptor 1, SNAP7941, had antidepressant and anxiolytic effects, in addition to anorectic effects, when administered intraperitoneally [80]. This observation suggests that an $\mathrm{MCH}$ receptor 1 antagonist may be useful not only in the management of obesity but also as a treatment for depression and/or anxiety. Alternatively, an $\mathrm{MCH}$ receptor agonist [81] may be useful for the treatment 
of anorexia, for example in cachectic patients with an advanced stage of cancer.

\section{Urocortins (human homologues of fish urotensin-I)}

Urotensins are peptide hormones that are secreted by the fish neuroendocrine organ located in the caudal spinal cord, urophysis [82-84]. Urotensin-I is a CRFlike peptide hormone [85] and urotensin-II is a somatostatin-like peptide in fishes [86]. Urocortin (now called urocortin 1) is a human homologue of urotensin1 and belongs to the CRF family [24, 87]. Human urocortin 1 has $63 \%$ identity with fish urotensin-I and $43 \%$ identity with rat/human CRF at the amino acid level (Table 2). Urotensin-II is described in latter section.

Urocortin 1 is a 40-amino acid peptide discovered originally in the rat midbrain. Human urocortin 1 is expressed in the brain and pituitary [87-90] as well as various peripheral tissues, such as gastrointestinal tract [91, 92], placenta, fetal membranes [93], ovaries [94], uterus [95], synovial tissue [96], and lymphocytes [97]. CRF receptors are classified into CRF type 1 receptor $\left(\mathrm{CRF}_{1}\right.$ receptor $)$ [98] and CRF type 2 receptor $\left(\mathrm{CRF}_{2}\right.$ receptor) [99]. $\mathrm{CRF}_{1}$ receptor is highly expressed in the brain and pituitary, and mediates the stress response and anxiety-related behavior, as well as ACTH release from the pituitary $[98,100] . \mathrm{CRF}_{2}$ receptor is expressed not only in the brain but also in the peripheral tissues, including heart and skeletal muscle tissues [99]. $\mathrm{CRF}_{2}$ receptor mediates stress-coping responses including anxiolysis, anorexia, vasodilatation, cardioprotection and dearousal [101-103]. Urocortin 1 binds with high affinity to both $\mathrm{CRF}_{1}$ receptor and $\mathrm{CRF}_{2}$ receptor, but this ligand has a much higher affinity for $\mathrm{CRF}_{2}$ receptor than CRF [24, 87]. The distribution of urocortin 1 nerve fibers in the brain correlates well with that of $\mathrm{CRF}_{2}$ receptor but not with that of $\mathrm{CRF}_{1}$ receptor [24]. Urocortin 1 is therefore considered to be a physiological ligand for $\mathrm{CRF}_{2}$ receptor.

There is accumulating evidence that indicates urocortin 1 has important pathophysiological roles in the cardiovascular regulation. Urocortin 1 has been demonstrated to have potent coronary vasodilatory and cardiac inotropic effects, and these effects have been shown to be more potent than CRF [104-106]. Urocortin 1 has protective effects on cardiac myocytes from ischemic or reperfusion injury [107-113]. These protective effects of urocortin were mediated by upregulation of $\mathrm{p} 42 / \mathrm{p} 44$ MAPK signaling pathway, activation of protein kinase $\mathrm{B} / \mathrm{Akt}$, and induction of $\mathrm{K}(\mathrm{ATP})$ channel gene expression. Moreover, urocortin 1 stimulates ANP and BNP secretions from neonatal rat cardiomyocytes [114].

CRF receptors, particularly $\mathrm{CRF}_{2}$ receptor, are expressed in the heart $[99,115-117] . \mathrm{CRF}_{2(\mathrm{a})}$ receptor mRNA was predominantly expressed in the four chambers of human heart [117] (Fig. 3). $\mathrm{CRF}_{1}$ receptor mRNA was only weakly expressed in some of these samples, and $\mathrm{CRF}_{2(\mathrm{~b})}$ receptor mRNA was expressed in the left atrium in all four cases and in the right atrium of only one out of four cases studied [117] (Fig. 3). Actually, CRF acted directly on cardiac myocytes, presumably through $\mathrm{CRF}_{2}$ receptor, to elevate intracellular cAMP levels [115]. Physiological ligands for $\mathrm{CRF}_{2}$ receptor in the cardiac myocardium, however, had long been unknown, because plasma levels of CRF are very low and CRF expression in the heart was very weak or undetectable [115]. Very recently, several investigators, including our group, have shown that both urocortin $1 \mathrm{mRNA}$ and peptide are expressed in the heart [107, 108, 117, 118]. Urocortin 1 mRNA was expressed in all four chambers of human heart [117] (Fig. 3). Immunoreactive-urocortin 1 was present in the human heart at levels comparable to those found in the brain [117] (Fig. 4). Urocortin 1 was expressed in rat cardiomyocytes, and its expression levels increased by heat shock and ischemia [107, 108]. Nishikimi et al. [118] have reported that the human myocardium was immunohistochemically positive for urocortin 1 , the staining of which was more intense in the failing heart. Actually in sheep with experimental heart failure, intravenous infusion of urocortin showed beneficial hemodynamic, endocrine and renal effects, such as increased cardiac output, decreased peripheral resistance, decreased plasma concentrations of renin, aldosterone, and endothelin-1, and increased urine volume and sodium excretion [119].

Another important aspect of urocortin is its relation to inflammation [120]. Urocortin 1 is expressed in immune tissues, such as thymus and spleen [121-123], and immune cells, such as lymphocytes [96, 97] and macrophages [92]. Urocortin $1 \mathrm{mRNA}$ expression increased in thymus after immune activation by lipopolysaccharide in a corticosterone-dependent manner 
Table 2. Amino acid sequences of human corticotropin-releasing factor (CRF), fish urotensin-I (85), urocortin 1, urocortin 2 , stresscopin-related peptide (SRP), urocortin 3 and stresscopin

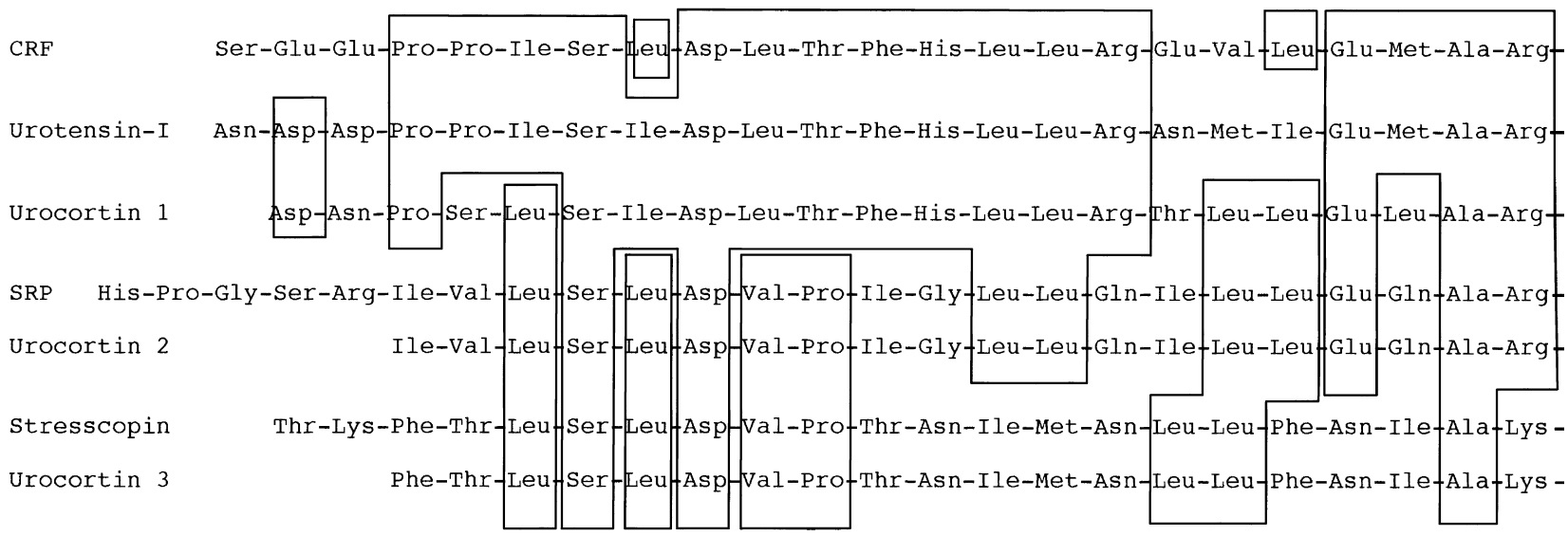

Amino acids commonly found among CRF, fish urotensin-I, urocortin 1, urocortin 2 (SRP) and urocortin 3 (stresscopin) are shown by squares.

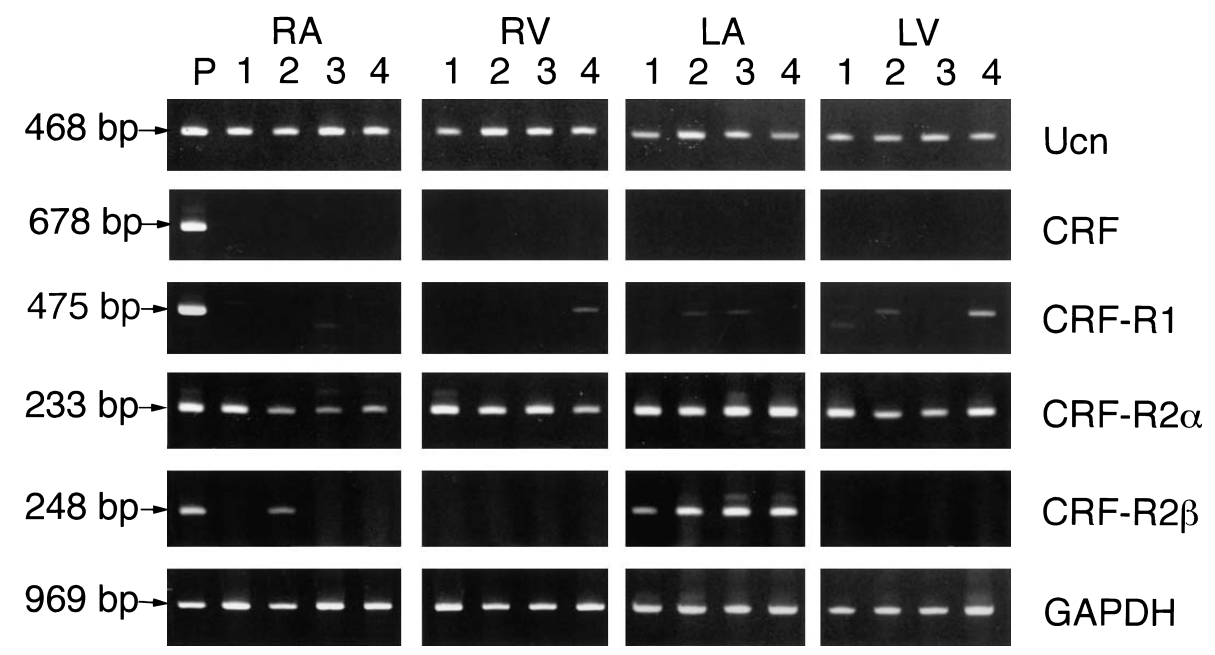

Fig. 3. RT-PCR analysis for urocortin 1 (Ucn), CRF, CRF type 1 receptor (CRF-R1), CRF type 2(a) receptor (CRF-R2 $\alpha$ ), and CRF type 2(b) receptor (CRF-R2 $\beta$ in four human hearts (patients $1-4$ ) in the four constituent chambers (RA, right atrium; RV, right ventricle; LA, left atrium; LV, left ventricle). Total RNA from placenta, pituitary gland, hypothalamus, and left atrium were used as positive controls for urocortin and CRF, CRF-R1, -R2 $\alpha$, and -R2 $\beta$, respectively. The bottom panel shows GAPDH employed as an internal control. P, Positive control. Reproduced from ref [117] Kimura et al. J Clin Endocrinol Metab 87: 340-346; 2002 with kind permission from the Endocrine Society.

[121]. Furthermore, urocortin 1 expression in the synovial was increased in rheumatoid arthritis [96]. Urocortin 1 expression was observed in synovial cells, lymphocytes, macrophages, and fibroblasts in the synovial tissue obtained from patients with rheumatoid arthritis [96]. Urocortin 1 was present in the gastric mucosa, and the level of immunoreactive-urocortin 1 was higher in gastric biopsies from the group of patients with active Helicobacter pylori gastritis than in normal controls [122]. It was reported that urocortin 1 , as well as CRF, suppressed experimental auto- immune encephalomyelitis [124]. Intracerebroventricular injection of urocortin 1 produced a marked decrease in the proliferative response of splenocytes to a mitogen, suggesting that urocortin 1 is involved in the brain control of peripheral immune functions, such as stress-induced immunosuppression, via the sympathetic nervous system [125]. On the other hand, urocortin 1 has been shown to be one of the most potent triggers of mast cell degradation and skin vascular permeability [126]. Thus, urocortin 1 expression appears to be increased in inflammatory conditions of various 
Table 2. (continued)

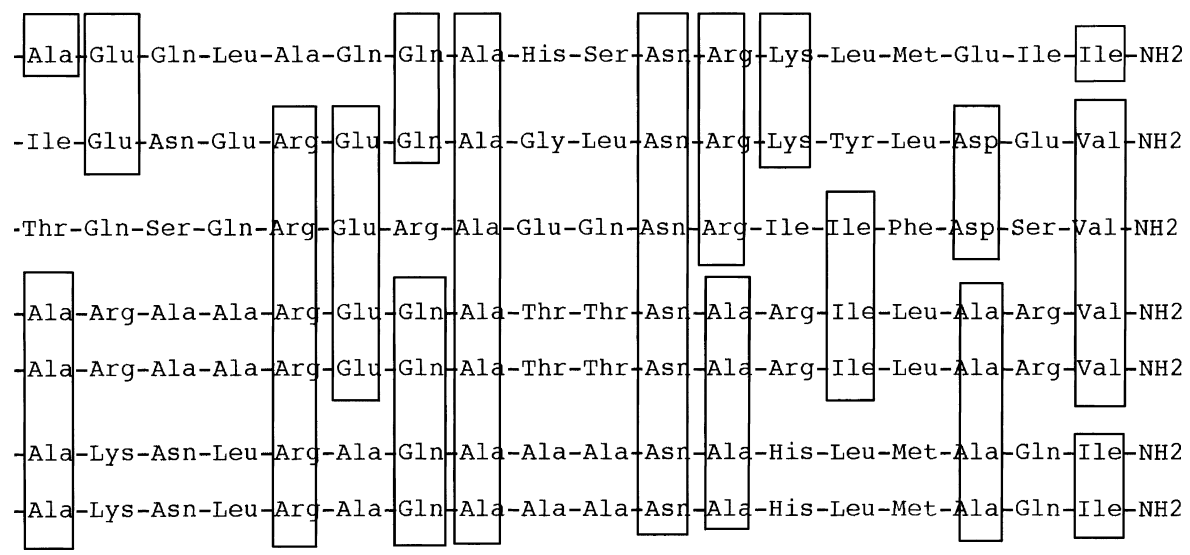

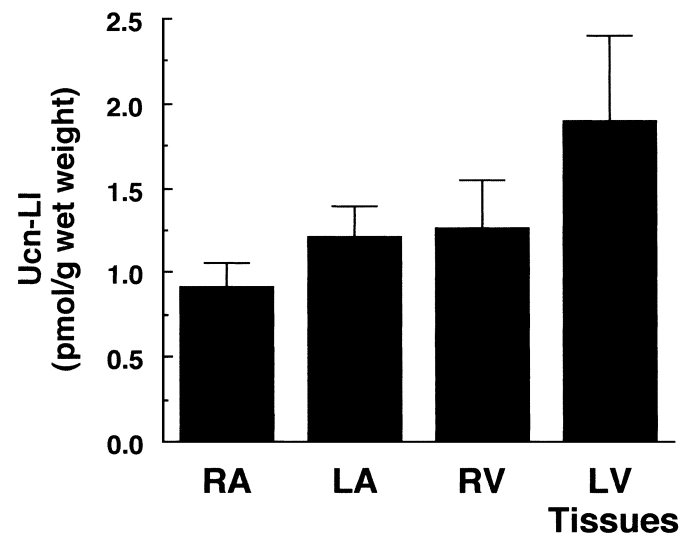

Fig. 4. Urocortin 1-like immunoreactivity in the human heart (mean $\pm \mathrm{SEM}, \mathrm{n}=4$ ). $\mathrm{RA}$, right atrium; $\mathrm{RV}$, right ventricle; $\mathrm{LA}$, left atrium; $\mathrm{LV}$, left ventricle. Reproduced from ref [117] Kimura et al. J Clin Endocrinol Metab 87: 340-346; 2002 with kind permission from the Endocrine Society.

diseases, and urocortin may modulate local inflammatory states.

Urocortin 1-deficient mice displayed an impaired acoustic startle response, suggesting that urocortin 1 modulates the acoustic startle response through the urocortin 1-expressing neuron projections from the region of the Edinger-Westphal nucleus [127, 128]. On the other hand, there was inconsistency in the results of stress-induced anxiety behavior between these two reports: Vetter et al. reported that these mice showed increased anxiety-like behavior [127], whereas Wang et al. reported that the mice showed normal stress- induced anxiety behavior and autonomic control [128]. It is not known whether these urocortin-deficient mice show altered cardiovascular and/or inflammatory responses to various stressful stimuli.

Recent studies have shown the presence of two other isopeptides of urocortin 1; urocortin 2 (stresscopinrelated peptide) $[129,130]$ and urocortin 3 (stresscopin) (Table 3) [130-132], both of which are specific ligands for $\mathrm{CRF}_{2}$ receptor and do not bind to $\mathrm{CRF}_{1}$ receptor. Two research groups identified two cDNAs encoding peptides similar to urocortin 1 and CRF. Different interpretations of post-translational processing sites resulted in slightly different amino acid sequences of the peptides: Human urocortin 3 is a 38 amino acid peptide that corresponds to the sequence 3-40 of human stresscopin, a 40 amino acid peptide, while human urocortin 2 (urocortin-related peptide sequence) is a 38 amino acid that corresponds to the sequence of 6-43 of stresscopin-related peptide, a 43 amino acid. Urocortin 2 and urocortin 3 have about 20-40\% homology with CRF and urocortin 1 (Table $3)$. The homology between urocortin 2 and urocortin 3 was about $40 \%$. Urocortin 2 and urocortin 3 are both widely expressed in the brain and the peripheral tissues. The presence of urocortin 2, however, has not been clarified in the human tissues, because the human sequence lacks a consensus proteolytic cleavage site that would allow for C-terminal processing of the peptide. Further studies are therefore required to clarify whether urocortin 2 is a real peptide or merely an artifact in human.

Urocortin 3-positive neurons were found predomi- 
Table 3. Amino acid sequences of human urotensin-II, goby urotensin-II (86) and human somatostatin-14

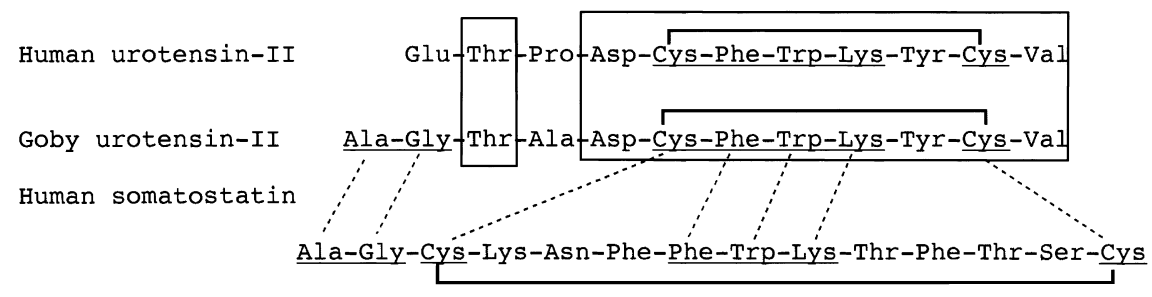

Amino acids commonly found in human and goby urotensin-II are shown by squares. Amino acids commonly found in somatostatin and urotensin-II are underlined.

nantly within the hypothalamus and medial amygdala of rat brain. The urocortin 3 fibers were distributed mainly in the hypothalamus and limbic structures [133]. Although further studies are required to clarify the physiological significance of these two novel urocortin isopeptides, at least urocortin 3 may act as an important mediator working against stress through their actions on $\mathrm{CRF}_{2}$ receptor, such as anxiolysis, anorexia, vasodilatation, cardioprotection and dearousal.

\section{Urotensin-II}

Urotensin-II is a "somatostatin-like" cyclic peptide which was originally isolated from fish urophysis [86, 134]. Human urotensin-II is an 11-amino-acid peptide $[25,26]$ (Table 3$)$. The reverse pharmacological approach has shown that human urotensin-II is an agonist for the orphan receptor GPR14 [26]. Urotensin-II is a potent vasoconstrictor peptide and its vasoconstrictive potency is one order of magnitude greater than endothelin-1 $[26,135]$. On the other hand, urotensin-II elic- ited vasodilatation in some arteries, possibly through the release of endothelium-derived hyperpolarizing factor and nitric oxide [136, 137]. In addition to actions on vascular vessels, this peptide has a positive inotropic action [138], stimulates proliferation of vascular smooth muscle cells [139-141], and induces hypertrophic responses in cultured cardiomyocytes [142]. Furthermore, it inhibited insulin release from the perfused rat pancreas [143].

Urotensin-II and urotensin-II receptor are expressed in various human tissues including brain, heart and kidney [26, 144] (Fig. 5). We have shown for the first time the presence of urotensin-II-like immunoreactivity in human plasma [144] (Fig. 6). The levels of plasma urotensin-II-like immunoreactivity were elevated in patients with chronic renal failure. Plasma concentrations of urotensin-II-like immunoreactivity were 2-fold higher in patients not on dialysis and 3fold higher in those on hemodialysis than in healthy individuals (Fig. 6). Kidneys play important roles in the metabolism and the elimination of many peptide hormones. Decreased elimination of urotensin-II from

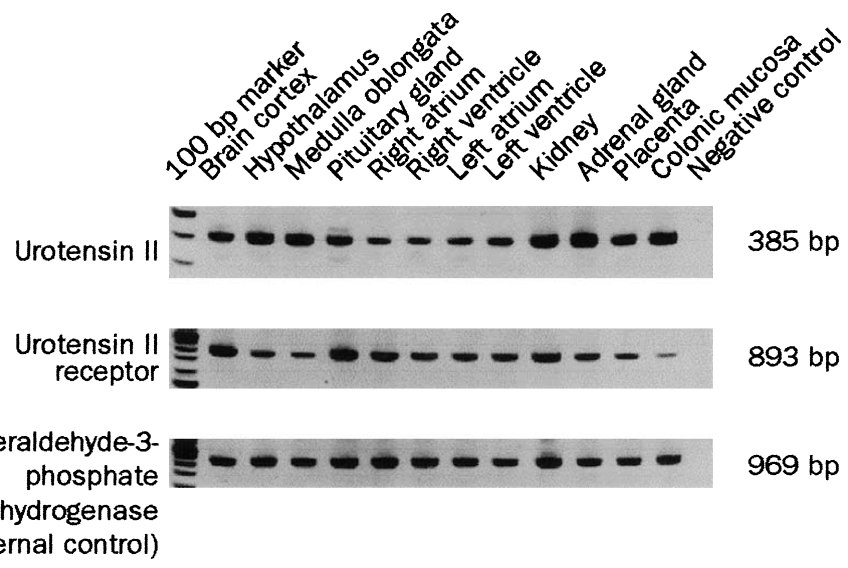

Fig. 5. Urotensin II and urotensin II receptor messenger RNA expression in various tissues. Reproduced from ref [144] Totsune et al. Lancet 358: 810-811; 2001 with kind permission from the Lancet. 


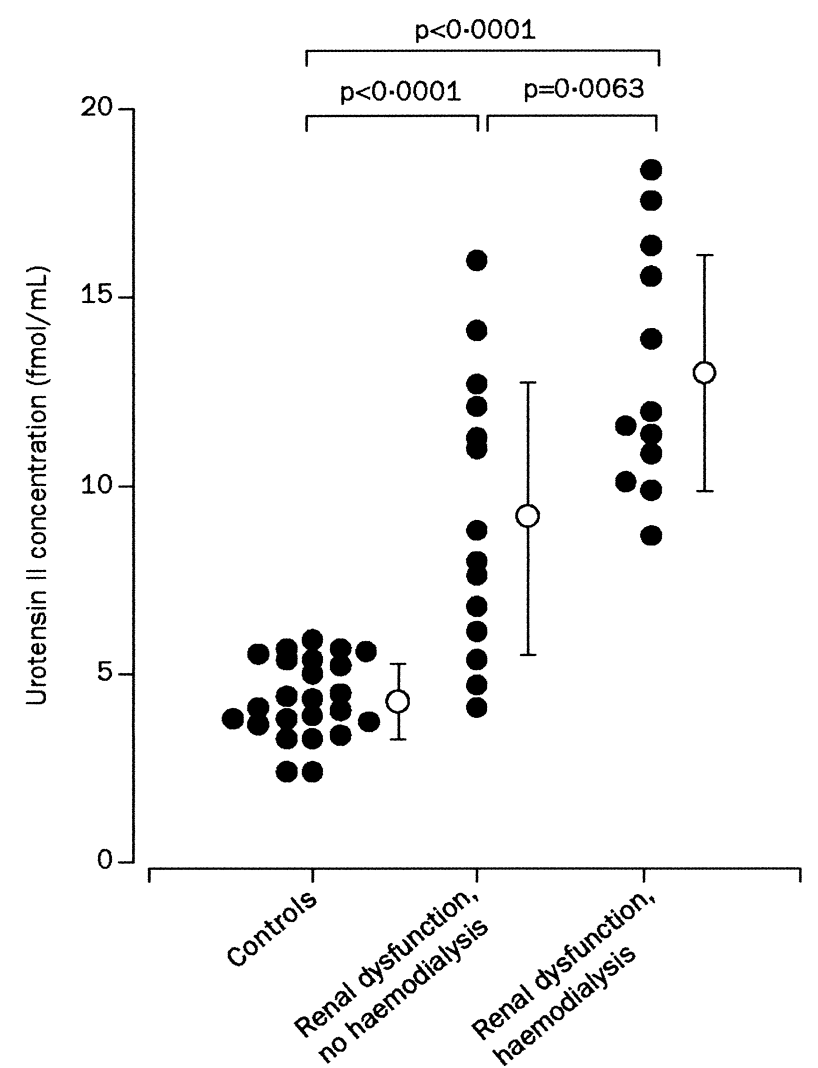

Fig. 6. Plasma concentrations of urotensin II in patients with chronic renal failure. Open circles and bars show mean and SD, respectively. Reproduced from ref [144] Totsune et al. Lancet 358: 810-811; 2001 with kind permission from the Lancet.

blood may explain increased plasma levels of urotensin-II-like immunoreactivity in patients with chronic renal failure. Urotensin-II-like immunoreactivity was present in the human urine [145]. In the kidney, urotensin-II was expressed in the epithelial cells of tubules and ducts and in the endothelial cells of renal capillaries [146]. Urotensin-II secreted by renal tubular cells into urine may account for urotensin-II-like immunoreactivity in urine. Urotensin-II produced by kidneys may also have roles in the renal circulation and the water-electrolyte transport in the kidney.

Subsequent studies have shown that plasma levels of urotensin-II-like immunoreactivity were also increased in patients with heart failure [147, 148], liver cirrhosis and portal hypertension [149], or diabetes mellitus [150]. Urotensin-II was strongly expressed in the cardiomyocytes in patients with end stage congestive heart failure, suggesting that cardiomyocytes are one of the major source of elevated plasma urotensin-
II in these patients [151]. Plasma levels of urotensinII-like immunoreactivity were elevated in patients with diabetes mellitus without renal failure (with normal serum creatinine) regardless of the presence or absence of proteinuria [150]. Because urotensin-II was expressed in cultured vascular endothelial cells, vascular endothelial damage accompanied with diabetes mellitus may account for the elevation of plasma urotensinII-like immunoreactivity. Interestingly, the association of certain polymorphism in the urotensin-II gene with type 2 diabetes mellitus has been reported in the Chinese population [152] and the Japanese population [153]. Urotensin-II may be related not only to the diabetic vascular complications, but also to the control of carbohydrate metabolism.

On the other hand, it should be noted that plasma concentrations of urotensin-II-like immunoreactivity measured by enzyme-linked immunosorbent assay were extremely high $[149,154]$, when compared with the concentrations measured by radioimmunoassay after the extraction [144, 147, 148, 150]. In control subjects, plasma concentrations of urotensin-II-like immunoreactivity measured by enzyme-linked immunosorbent assay were about 150-600 times higher $[149,154]$ than those measured by radioimmunoassay after the extraction $[144,147,148,150]$. This may suggest that the measurement of unextracted plasma by enzyme-linked immunosorbent assay may be affected by non-specific effects of proteins in plasma, and that the extraction procedure of plasma samples is essential for the precise measurement of plasma urotensin-II-like immunoreactivity.

Another possible pathophysiological role of urotensin-II may be a growth stimulatory effect, particularly in tumors. Urotensin-II and its receptor are expressed in various tumor cell lines, such as $\mathrm{T} 98 \mathrm{G}$ glioblastoma cells, SW-13 adrenocortical carcinoma cells, DLD-1 colorectal adenocarcinoma cells and HeLa cervical cancer cells [155, 156] (Fig. 7). Reversetranscriptase polymerase chain reaction revealed expression of urotensin-II and its receptor in the normal adrenal glands and tumor tissues of adrenocortical tumors and pheochromocytomas [157]. The growth stimulatory effects were found not only in vascular smooth muscle cells [139-141], but also in SW-13 adrenocortical carcinoma cells and VMRC-RCW renal cell carcinoma cells [157]. Ziltener et al. reported that the proliferative action of urotensin-II is mediated by the long-lasting activation of extracellular signal- 


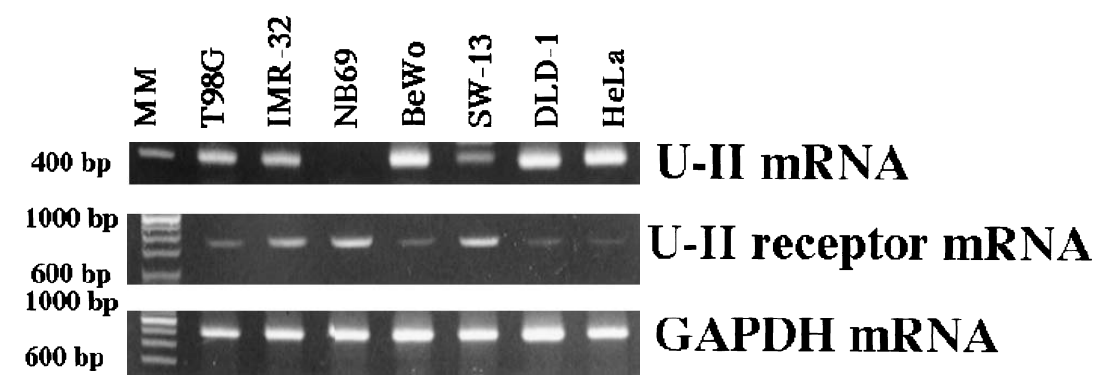

Fig. 7. Reverse transcriptase-polymerase chain reaction of urotensin II (U-II) mRNA and urotensin II receptor (U-II receptor) mRNA in various human tumor cell lines; T98G glioblastoma cells, IMR-32 neuroblastoma cells, NB69 neuroblastoma cells, BeWo choriocarcinoma cells, SW-13 adrenocortical carcinoma cells, DLD-1 colorectal adenocarcinoma cells and HeLa cervical cancer cells. The lower panel indicates expression of glyceraldehyde-3-phosphate dehydrogenase (GAPDH) mRNA as an internal control. MM, molecular weight markers expressed in base pairs (bp). Reproduced from ref [155] Takahashi et al. Peptides 22: 1175-1179; 2001 with kind permission from Elsevier Science.

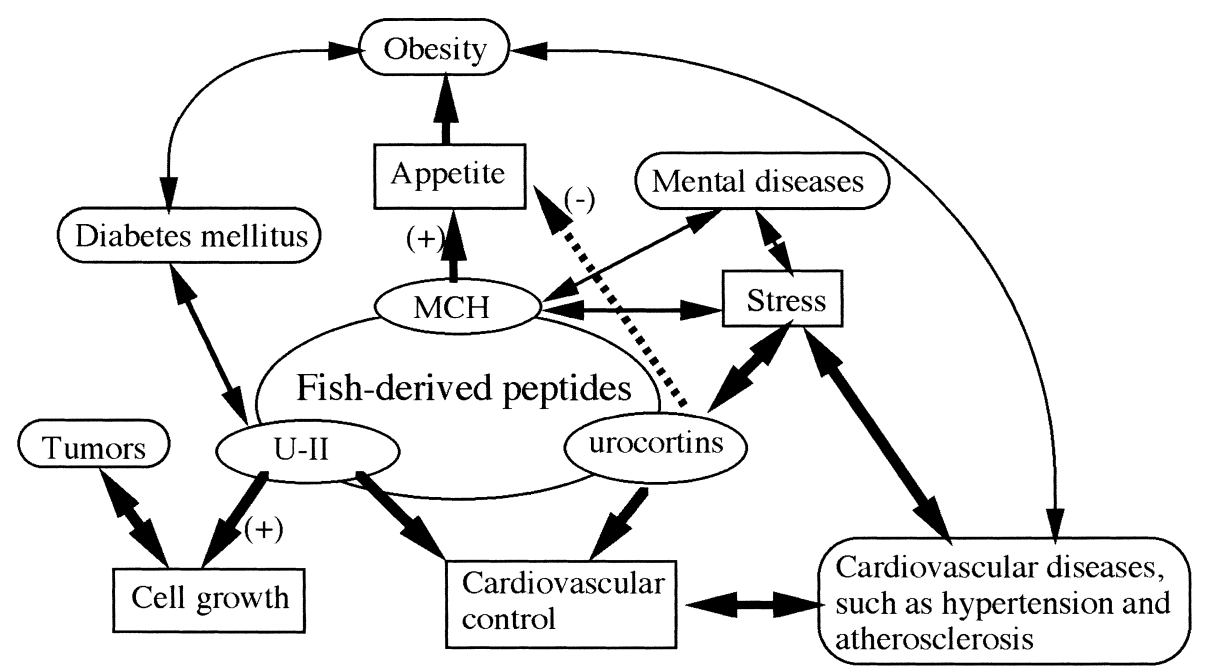

Fig. 8. Possible relations of fish-derived peptides to human physiology and diseases. MCH, melanin-concentrating hormone. U-II, urotensin II. (+), positive regulation. (-), negative regulation.

regulated kinase 1/2 (ERK1/2) [158]. Thus, urotensin-II may act as an autocrine growth stimulator in various types of tumors, as well as in other benign disorders, such as atherosclerosis, cardiac hypertrophy and proliferative glomerulonephritis.

\section{Possible translational medicine related to fish-derived peptides}

The impact of fish endocrinology on human physiology and diseases has long been ignored [159]. It is evident, however, that fish-derived peptides are involved in the control and regulation of the fundamental mammalian physiology, such as appetite regulation, stress response, cardiovascular regulation and cell proliferation (Fig. 8). These peptides may therefore be related to various diseases, such as obesity-related diseases, cardiovascular diseases, diabetes mellitus, and neoplastic diseases as well as mental diseases. Development of antagonists or agonists for the receptors of these peptides may open new strategy of treatment of many diseases, such as obesity, anorexia, cardiovascular diseases such as hypertension and coronary artery diseases, and various types of tumors. Actually, one recently developed antagonist for the $\mathrm{MCH}$ receptor 1, SNAP-7941, was reported to have appetite-suppressing effects, as well as antidepressant and anxiolytic effects [80]. 


\section{Acknowledgments}

I am very grateful to my colleagues: Dr. Kazuhito Totsune, Dr. Zenei Arihara, Dr. Osamu Murakami (Neuroendocrinology Group, Department of Medicine, Tohoku University School of Medicine), Dr. Tomomi Kitamuro, Dr. Masaharu Nakayama, Dr. Tetsuo Udono, Dr. Reiko Udono-Fujimori, Dr. Yin Li, Dr. Masahiko Sone, Prof. Shigeki Shibahara (Department of Molecular Biology and Applied Physiology, Tohoku University School of Medicine), Prof. Hironobu Sasano (Department of Pathology, Tohoku University School of Medicine), Prof. Hiroshi Kawauchi (Kitasato Uni- versity, Sanriku, Iwate) and Dr. Toraichi Mouri (Mouri Clinic, Natori, Miyagi) for their encouragement and collaboration of my work. This work was supported in part by Grants-in-aid for Scientific Research (B) (No. 13470030 ) and (C) (No. 13671094), and a Grant-in-aid for Scientific Research on Priority Areas (A) (No. 13035005) from the Ministry of Education, Science, Sports and Culture of Japan, by Grants for the Renal Anemia Research (2000 and 2001), by a Research Grant from the HIROMI Medical Research Foundation (2001) and by a Research Grant from the Intelligent Cosmos (2002).

\section{References}

1. Takahashi K (2001) Adrenomedullin from a pheochromocytoma to the eye: implications of the adrenomedullin research for endocrinology in the 21 st century. Tohoku J Exp Med 193: 79-114. Review.

2. Burgus R, Guillemin R (1970) Hypothalamic releasing factors. Annu Rev Biochem 39: 499-526.

3. Schally AV, Arimura A, Kastin AJ (1973) Hypothalamic regulatory hormones. Science 179: 341-350.

4. Vale W, Spiess J, Rivier C, Rivier J (1981) Characterization of a 41-residue ovine hypothalamic peptide that stimulates secretion of corticotropin and beta-endorphin. Science 213: 1394-1397.

5. Tatemoto K, Carlquist M, Mutt V (1982) Neuropeptide $\mathrm{Y}$ - a novel brain peptide with structural similarities to peptide YY and pancreatic polypeptide. Nature 296: 659-660.

6. Kangawa K, Matsuo H (1984) Purification and complete amino acid sequence of alpha-human atrial natriuretic polypeptide (alpha-hANP). Biochem Biophys Res Comm 118: 131-139.

7. Yanagisawa M, Kurihara H, Kimura S, Tomobe Y, Kobayashi M, Mitsui Y, Yazaki Y, Goto K, Masaki T (1988) A novel potent vasoconstrictor peptide produced by vascular endothelial cells. Nature 332: 411415.

8. Takahashi K (2001) Adrenomedullin: from a pheochromocytoma to the eyes. Peptides 22: 1691.

9. Eto T (2001) A review of the biological properties and clinical implications of adrenomedullin and proadrenomedullin N-terminal 20 peptide (PAMP), hypotensive and vasodilating peptides. Peptides 22: 16931711. Review.

10. Tomoda Y, Isumi Y, Katafuchi T, Minamino N (2001) Regulation of adrenomedullin secretion from cultured cells. Peptides 22: 1783-1794.

11. Nakayama M, Takahashi K, Murakami O, Murakami H, Sasano H, Shirato K, Shibahara S (1999) Adreno- medullin in monocytes and macrophages: possible involvement of macrophage-derived adrenomedullin in atherogenesis. Clin Sci (Lond) 97: 247-251.

12. Takahashi K, Nakayama M, Totsune K, Murakami O, Sone M, Kitamuro T, Yoshinoya A, Shibahara S (2000) Increased secretion of adrenomedullin from cultured human astrocytes by cytokines. $J$ Neurochem 74: 99-103.

13. Udono T, Takahashi K, Nakayama M, Yoshinoya A, Totsune K, Murakami O, Durlu YK, Tamai M, Shibahara S (2001) Induction of adrenomedullin by hypoxia in cultured retinal pigment epithelial cells. Invest Ophthalmol Vis Sci 42: 1080-1086.

14. Udono T, Takahashi K, Nakayama M, Murakami O, Durlu YK, Tamai M, Shibahara S (2000) Adrenomedullin in cultured human retinal pigment epithelial cells. Invest Ophthalmol Vis Sci 41: 1962-1970.

15. Satoh F, Takahashi K, Murakami O, Totsune K, Sone M, Ohneda M, Abe K, Miura Y, Hayashi Y, Sasano H, Mouri T (1995) Adrenomedullin in human brain, adrenal glands and tumor tissues of pheochromocytoma, ganglioneuroblastoma and neuroblastoma. J Clin Endocrinol Metab 80: 1750-1752.

16. Miller MJ, Martinez A, Unsworth EJ, Thiele CJ, Moody TW, Elsasser T, Cuttitta F (1996) Adrenomedullin expression in human tumor cell lines. Its potential role as an autocrine growth factor. $J$ Biol Chem 271: 23345-23351.

17. Takahashi K, Satoh F, Hara E, Sone M, Murakami O, Kayama T, Yoshimoto T, Shibahara S (1997) Production and secretion of adrenomedullin from glial cell tumors and its effects on cAMP production. Peptides 18: 1117-1124.

18. Nakayama M, Takahashi K, Murakami O, Shirato K, Shibahara S (1998) Induction of adrenomedullin by hypoxia and cobalt chloride in human colorectal carcinoma cells. Biochem Biophys Res Comm 243: 514 
517.

19. Takahashi K, Satoh F, Sone M, Totsune K, Arihara Z, Noshiro T, Mouri T, Murakami O (1998) Expression of adrenomedullin mRNA in adrenocortical tumors and secretion of adrenomedullin by cultured adrenocortical carcinoma cells. Peptides 19: 1719-1724.

20. Takahashi K, Totsune K, Kitamuro T, Sone M, Murakami O, Shibahara S (2002) Three vasoactive peptides, endothelin-1, adrenomedullin and urotensinII, in human tumour cell lines of different origin: expression and effects on proliferation. Clin Sci (Lond) 103 (Suppl 48): 35S-38S.

21. Takahashi K, Totsune K, Murakami O (2002) Adrenocortical peptides: autocrine or paracrine regulators for the steroid hormone secretion or the cell proliferation? Exp Clin Endocrinol Diabetes 110: 373-380.

22. Kawauchi H, Kawazoe I, Tsubokawa M, Kishida M, Baker BI (1983) Characterization of melanin-concentrating hormone in chum salmon pituitaries. Nature 305: 321-323.

23. Lederis $\mathrm{K}$, Letter $\mathrm{A}$, McMaster $\mathrm{D}$, Ichikawa $\mathrm{T}$, MacCannell KL, Kobayashi Y, Rivier J, Rivier C, Vale W, Fryer J (1983) Isolation, analysis of structure, synthesis, and biological actions of urotensin I neuropeptides. Can J Biochem Cell Biol 61: 602-614.

24. Vaughan J, Donaldson C, Bittencourt J, Perrin MH, Lewis K, Sutton S, Chan R, Turnbull AV, Lovejoy D, Rivier C, Rivier J, Sawchenko PE, Vale W (1995) Urocortin, a mammalian neuropeptide related to fish urotensin I and to corticotropin-releasing factor. Nature 378: 287-292.

25. Coulouarn Y, Lihrmann I, Jegou S, Anouar Y, Tostivint H, Beauvillain JC, Conlon JM, Bern HA, Vaudry H (1998) Cloning of the cDNA encoding the urotensin II precursor in frog and human reveals intense expression of the urotensin II gene in motoneurons of the spinal cord. Proc Natl Acad Sci USA 95: 15803-15808.

26. Ames RS, Sarau HM, Chambers JK, Willette RN, Aiyar NV, Romanic AM, Louden CS, Foley JJ, Sauermelch CF, Coatney RW, Ao Z, Disa J, Holmes SD, Stadel JM, Martin JD, Liu WS, Glover GI, Wilson S, McNulty DE, Ellis CE, Elshourbagy NA, Shabon U, Trill JJ, Hay DW, Ohlstein EH, Bergsma DJ, Douglas SA (1999) Human urotensin-II is a potent vasoconstrictor and agonist for the orphan receptor GPR14. Nature 401: 282-286.

27. Hogben L I, Slome D (1931) The pigmentary effector system. VI. The dual character of endocrine coordination in amphibian colour change. Proc $R$ Soc London Ser B 108: 10-53.

28. Naito N, Nakai Y, Kawauchi H, Hayashi Y (1985) Immunocytochemical identification of melanin-concentrating hormone in the brain and pituitary gland of the teleost fishes Oncorhynchus-keta and Salmo-gairdneri. Cell Tissue Res 242: 41-48.

29. Bird DJ, Baker BI, Kawauchi H (1989) Immuno- cytochemical demonstration of melanin-concentrating hormone and proopiomelanocortin-like products in the brain of the trout and carp. Gen Comp Endocrinol 74: 442-450.

30. Eberle AN, Baker BI, Kishida M, Baumann JB, Girard J (1989) Melanin concentrating hormone. IV. Development of a sensitive solid-phase radioimmunoassay for melanin-concentrating hormone. Life Sci 45: 1149-1154.

31. Kishida M, Baker BI, Eberle AN (1989) The measurement of melanin-concentrating hormone in trout blood. Gen Comp Endocrinol 74: 221-229.

32. Green JA, Baker BI (1991) The influence of repeated stress on the release of melanin-concentrating hormone in the rainbow trout. $J$ Endocrinol 128: 261-266.

33. Green JA, Baker BI, Kawauchi H (1991) The effect of rearing rainbow trout on black or white backgrounds on their secretion of melanin-concentrating hormone and their sensitivity to stress. J Endocrinol 128: 267274.

34. Baker BI, Bird DJ, Buckingham JC (1985) Salmonid melanin-concentrating hormone inhibits corticotrophin release. J Endocrinol 106: R5-8.

35. Baker BI, Bird DJ, Buckingham JC (1986) Effects of chronic administration of melanin-concentrating hormone on corticotrophin, melanotrophin, and pigmentation in the trout. Gen Comp Endocrinol 63: 62-69.

36. Vaughan JM, Fischer WH, Hoeger C, Rivier J, Vale W (1989) Characterization of melanin-concentrating hormone from rat hypothalamus. Endocrinology 125: 1660-1665.

37. Nahon JL, Presse F, Bittencourt JC, Sawchenko PE, Vale W (1989) The rat melanin-concentrating hormone messenger ribonucleic acid encodes multiple putative neuropeptides coexpressed in the dorsolateral hypothalamus. Endocrinology 125: 2056-2065.

38. Presse F, Nahon JL, Fischer WH, Vale W (1990) Structure of the human melanin concentrating hormone mRNA. Mol Endocrinol 4: 632-637.

39. Zamir N, Skofitsch G, Bannon MJ, Jacobowitz DM (1986) Melanin-concentrating hormone: unique peptide neuronal system in the rat brain and pituitary gland. Proc Natl Acad Sci USA 83: 1528-1531.

40. Bittencourt JC, Presse F, Arias C, Peto C, Vaughan J, Nahon JL, Vale W, Sawchenko PE (1992) The melanin-concentrating hormone system of the rat brain: an immuno- and hybridization histochemical characterization. J Comp Neurol 319: 218-245.

41. Presse F, Hervieu G, Imaki T, Sawchenko PE, Vale W, Nahon JL (1992) Rat melanin-concentrating hormone messenger ribonucleic acid expression: marked changes during development and after stress and glucocorticoid stimuli. Endocrinology 131: 1241-1250.

42. Pelletier G, Guy J, Desy L, Li S, Eberle AN, Vaudry H (1987) Melanin-concentrating hormone (MCH) is colocalized with alpha-melanocyte-stimulating hormone (alpha-MSH) in the rat but not in the human 
hypothalamus. Brain Res 423: 247-253.

43. Bresson JL, Clavequin MC, Fellmann D, Bugnon C (1989) Human hypothalamic neuronal system revealed with a salmon melanin-concentrating hormone $(\mathrm{MCH})$ antiserum. Neurosci Lett 102: 39-43.

44. Mouri T, Takahashi K, Kawauchi H, Sone M, Totsune K, Murakami O, Itoi K, Ohneda M, Sasano H, Sasano N (1993) Melanin-concentrating hormone in the human brain. Peptides 14: 643-646.

45. Takahashi K, Mouri T, Totsune K, Sone M, Murakami O, Itoi K, Ohneda M, Sasano H, Sasano N, Kawauchi $\mathrm{H}$ (1993) Human melanin-concentrating hormone in the human brain. Ann NY Acad Sci 680: 619-620.

46. Takahashi K, Suzuki H, Totsune K, Murakami O, Satoh F, Sone M, Sasano H, Mouri T, Shibahara S (1995) Melanin-concentrating hormone in human and rat. Neuroendocrinology 61: 493-498.

47. Qu D, Ludwig DS, Gammeltoft S, Piper M, Pelleymounter MA, Cullen MJ, Mathes WF, Przypek R, Kanarek R, Maratos-Flier E (1996) A role for melaninconcentrating hormone in the central regulation of feeding behaviour. Nature 380: 243-247.

48. Shimada M, Tritos NA, Lowell BB, Flier JS, MaratosFlier E (1998) Mice lacking melanin-concentrating hormone are hypophagic and lean. Nature 396: 670674.

49. Knigge KM, Baxter-Grillo D, Speciale J, Wagner J (1996) Melanotropic peptides in the mammalian brain: the melanin-concentrating hormone. Peptides 17: 10631073.

50. Knigge KM, Wagner JE (1997) Melanin-concentrating hormone $(\mathrm{MCH})$ involvement in pentylenetetrazole (PTZ)-induced seizure in rat and guinea pig. Peptides 18: 1095-1097.

51. Jezova D, Bartanusz V, Westergren I, Johansson BB, Rivier J, Vale W, Rivier C (1992) Rat melanin-concentrating hormone stimulates adrenocorticotropin secretion: evidence for a site of action in brain regions protected by the blood-brain barrier. Endocrinology 130: 1024-1029.

52. Navarra P, Tsagarakis S, Coy DH, Rees LH, Besser GM, Grossman AB (1990) Rat melanin concentrating hormone does not modify the release of CRH-41 from rat hypothalamus or ACTH from the anterior pituitary in vitro. $J$ Endocrinol 127: R1-4.

53. Gonzalez MI, Baker BI, Wilson CA (1997) Stimulatory effect of melanin-concentrating hormone on luteinising hormone release. Neuroendocrinology 66: 254262.

54. Chiocchio SR, Gallardo MG, Louzan P, Gutnisky V, Tramezzani JH (2001) Melanin-concentrating hormone stimulates the release of luteinizing hormone-releasing hormone and gonadotropins in the female rat acting at both median eminence and pituitary levels. Biol Reprod 64: 1466-1472.

55. Gonzalez MI, Vaziri S, Wilson CA (1996) Behavioral effects of alpha-MSH and MCH after central administration in the female rat. Peptides 17: 171-177.

56. Tsukamura H, Thompson RC, Tsukahara S, Ohkura S, Maekawa F, Moriyama R, Niwa Y, Foster DL, Maeda $\mathrm{K}$ (2000) Intracerebroventricular administration of melanin-concentrating hormone suppresses pulsatile luteinizing hormone release in the female rat. J Neuroendocrinol 12: 529-534.

57. Kennedy AR, Todd JF, Stanley SA, Abbott CR, Small CJ, Ghatei MA, Bloom SR (2001) Melanin-concentrating hormone $(\mathrm{MCH})$ suppresses thyroid stimulating hormone (TSH) release, in vivo and in vitro, via the hypothalamus and the pituitary. Endocrinology 142: 3265-3268.

58. Monzon ME, de Souza MM, Izquierdo LA, Izquierdo I, Barros DM, de Barioglio SR (1999) Melanin-concentrating hormone $(\mathrm{MCH})$ modifies memory retention in rats. Peptides 20: 1517-1519.

59. Bradley RL, Kokkotou EG, Maratos-Flier E, Cheatham B (2000) Melanin-concentrating hormone regulates leptin synthesis and secretion in rat adipocytes. Diabetes 49: 1073-1077.

60. Bradley RL, Mansfield JP, Maratos-Flier E, Cheatham B (2002) Melanin-concentrating hormone activates signaling pathways in 3T3-L1 adipocytes. Am J Physiol Endocrinol Metab 283: E584-592.

61. Stricker-Krongrad A, Dimitrov T, Beck B (2001) Central and peripheral dysregulation of melanin-concentrating hormone in obese Zucker rats. Brain Res Mol Brain Res 92: 43-48.

62. Chambers J, Ames RS, Bergsma D, Muir A, Fitzgerald LR, Hervieu G, Dytko GM, Foley JJ, Martin J, Liu WS, Park J, Ellis C, Ganguly S, Konchar S, Cluderay J, Leslie R, Wilson S, Sarau HM (1999) Melanin-concentrating hormone is the cognate ligand for the orphan Gprotein-coupled receptor SLC-1. Nature 400: 261-265.

63. Saito Y, Nothacker HP, Wang Z, Lin SH, Leslie F, Civelli O (1999) Molecular characterization of the melanin-concentrating-hormone receptor. Nature 400: 265-269.

64. Shimomura Y, Mori M, Sugo T, Ishibashi Y, Abe M, Kurokawa T, Onda H, Nishimura O, Sumino Y, Fujino $M$ (1999) Isolation and identification of melaninconcentrating hormone as the endogenous ligand of the SLC-1 receptor. Biochem Biophys Res Comm 261: 622-626.

65. Bachner D, Kreienkamp H, Weise C, Buck F, Richter D (1999) Identification of melanin concentrating hormone $(\mathrm{MCH})$ as the natural ligand for the orphan somatostatin-like receptor 1 (SLC-1). FEBS Lett 457: 522-524.

66. Lembo PM, Grazzini E, Cao J, Hubatsch DA, Pelletier M, Hoffert C, St-Onge S, Pou C, Labrecque J, Groblewski T, O’Donnell D, Payza K, Ahmad S, Walker P (1999) The receptor for the orexigenic peptide melanin-concentrating hormone is a G-protein- 
coupled receptor. Nat Cell Biol 1: 267-271.

67. Ludwig DS, Mountjoy KG, Tatro JB, Gillette JA, Frederich RC, Flier JS, Maratos-Flier E (1998) Melaninconcentrating hormone: a functional melanocortin antagonist in the hypothalamus. Am J Physiol 274: E627-633.

68. Takahashi K, Totsune K, Murakami O, Sone M, Satoh F, Kitamuro T, Noshiro T, Hayashi Y, Sasano H, Shibahara S (2001) Expression of melanin-concentrating hormone receptor messenger ribonucleic acid in tumor tissues of pheochromocytoma, ganglioneuroblastoma, and neuroblastoma. J Clin Endocrinol Metab 86: 369-374.

69. An S, Cutler G, Zhao JJ, Huang SG, Tian H, Li W, Liang L, Rich M, Bakleh A, Du J, Chen JL, Dai K (2001) Identification and characterization of a melaninconcentrating hormone receptor. Proc Natl Acad Sci USA 98: 7576-7581.

70. Hill J, Duckworth M, Murdock P, Rennie G, SabidoDavid C, Ames RS, Szekeres P, Wilson S, Bergsma DJ, Gloger IS, Levy DS, Chambers JK, Muir AI (2001) Molecular cloning and functional characterization of $\mathrm{MCH} 2$, a novel human $\mathrm{MCH}$ receptor. $J$ Biol Chem 276: 20125-20129.

71. Wang S, Behan J, O’Neill K, Weig B, Fried S, Laz T, Bayne M, Gustafson E, Hawes BE (2001) Identification and pharmacological characterization of a novel human melanin-concentrating hormone receptor, $\mathrm{MCH}-$ R2. J Biol Chem 276: 34664-34670.

72. Sailer AW, Sano H, Zeng Z, McDonald TP, Pan J, Pong SS, Feighner SD, Tan CP, Fukami T, Iwaasa H, Hreniuk DL, Morin NR, Sadowski SJ, Ito M, Ito M, Bansal A, Ky B, Figueroa DJ, Jiang Q, Austin CP, MacNeil DJ, Ishihara A, Ihara M, Kanatani A, Van der Ploeg LH, Howard AD, Liu Q (2001) Identification and characterization of a second melanin-concentrating hormone receptor, MCH-2R. Proc Natl Acad Sci USA 98: 7564-7569.

73. Mori M, Harada M, Terao Y, Sugo T, Watanabe T, Shimomura Y, Abe M, Shintani Y, Onda H, Nishimura O, Fujino M (2001) Cloning of a novel G proteincoupled receptor, SLT, a subtype of the melaninconcentrating hormone receptor. Biochem Biophys Res Comm 283: 1013-1018.

74. Rodriguez M, Beauverger P, Naime I, Rique H, Ouvry C, Souchaud S, Dromaint S, Nagel N, Suply T, Audinot V, Boutin JA, Galizzi JP (2001) Cloning and molecular characterization of the novel human melanin-concentrating hormone receptor MCH2. Mol Pharmacol 60: 632-639.

75. Sone M, Takahashi K, Murakami O, Totsune K, Arihara Z, Satoh F, Sasano H, Ito H, Mouri T (2000) Binding sites for melanin-concentrating hormone in the human brain. Peptides 21: 245-250.

76. Marsh DJ, Weingarth DT, Novi DE, Chen HY, Trumbauer ME, Chen AS, Guan XM, Jiang MM, Feng
Y, Camacho RE, Shen Z, Frazier EG, Yu H, Metzger JM, Kuca SJ, Shearman LP, Gopal-Truter S, MacNeil DJ, Strack AM, MacIntyre DE, Van der Ploeg LH, Qian S (2002) Melanin-concentrating hormone 1 receptor-deficient mice are lean, hyperactive, and hyperphagic and have altered metabolism. Proc Natl Acad Sci USA 99: 3240-3245.

77. Chen Y, Hu C, Hsu CK, Zhang Q, Bi C, Asnicar M, Hsiung HM, Fox N, Slieker LJ, Yang DD, Heiman ML, Shi Y (2002) Targeted disruption of the melaninconcentrating hormone receptor-1 results in hyperphagia and resistance to diet-induced obesity. Endocrinology 143: 2469-2477.

78. Takekawa S, Asami A, Ishihara Y, Terauchi J, Kato K, Shimomura Y, Mori M, Murakoshi H, Kato K, Suzuki N, Nishimura O, Fujino M (2002) T-226296: a novel, orally active and selective melanin-concentrating hormone receptor antagonist. Eur J Pharmacol 438: 129135.

79. Bednarek MA, Hreniuk DL, Tan C, Palyha OC, MacNeil DJ, Van der Ploeg LH, Howard AD, Feighner SD (2002) Synthesis and biological evaluation in vitro of selective, high affinity peptide antagonists of human melanin-concentrating hormone action at human melanin-concentrating hormone receptor 1. Biochemistry 41: 6383-6390.

80. Borowsky B, Durkin MM, Ogozalek K, Marzabadi MR, DeLeon J, Lagu B, Heurich R, Lichtblau H, Shaposhnik Z, Daniewska I, Blackburn TP, Branchek TA, Gerald C, Vaysse PJ, Forray C (2002) Antidepressant, anxiolytic and anorectic effects of a melaninconcentrating hormone-1 receptor antagonist. Nat Med 8: 825-830.

81. Bednarek MA, Tan C, Hreniuk DL, Palyha OC, MacNeil DJ, Van Der Ploeg LH, Howard AD, Feighner SD (2002) Synthesis and biological evaluation in vitro of a selective, high potency peptide agonist of human melanin-concentrating hormone action at human melanin-concentrating hormone receptor $1 . J$ Biol Chem 277: 13821-13826.

82. Emani M (1959) The morphology and functional significance of the caudal neurosecretory system of fishes. In: Gorbman A (ed) Comparative Endocrinology. Wiley, New York, 697-724.

83. Moore G, Letter A, Tesanovic M, Lederis K (1975) Studies on molecular weights of two peptide hormones from the urophysis of white sucker (Catostomus commersoni). Can J Biochem 53: 242-247.

84. Chan DK, Bern HA (1976) The caudal neurosecretory system. A critical evaluation of the two-hormone hypothesis. Cell Tissue Res 174: 339-354. Review.

85. Lederis K, Letter A, McMaster D, Moore G, Schlesinger D (1982) Complete amino acid sequence of urotensin I, a hypotensive and corticotropin-releasing neuropeptide from Catostomus. Science 218: 162-165.

86. Pearson D, Shively JE, Clark BR, Geschwind II, Barkley 
M, Nishioka RS, Bern HA (1980) Urotensin II: a somatostatin-like peptide in the caudal neurosecretory system of fishes. Proc Natl Acad Sci USA 77: 5021-5024.

87. Donaldson CJ, Sutton SW, Perrin MH, Corrigan AZ, Lewis KA, Rivier JE, Vaughan JM, Vale WW (1996) Cloning and characterization of human urocortin. Endocrinology 137: 2167-2170.

88. Takahashi K, Totsune K, Sone M, Murakami O, Satoh F, Arihara Z, Sasano H, Iino K, Mouri T (1998) Regional distribution of urocortin-like immunoreactivity and expression of urocortin mRNA in the human brain. Peptides 19: 643-647.

89. Iino K, Sasano H, Oki Y, Andoh N, Shin RW, Kitamoto T, Totsune K, Takahashi K, Suzuki H, Nagura H, Yoshimi T (1997) Urocortin expression in human pituitary gland and pituitary adenoma. J Clin Endocrinol Metab 82: 3842-3850.

90. Iino K, Sasano H, Oki Y, Andoh N, Shin RW, Kitamoto T, Takahashi K, Suzuki H, Tezuka F, Yoshimi T, Nagura H (1999) Urocortin expression in the human central nervous system. Clin Endocrinol (Oxf) 50: 107114.

91. Harada S, Imaki T, Naruse M, Chikada N, Nakajima K, Demura H (1999) Urocortin mRNA is expressed in the enteric nervous system of the rat. Neurosci Lett 267: 125-128.

92. Muramatsu Y, Fukushima K, Iino K, Totsune K, Takahashi K, Suzuki T, Hirasawa G, Takeyama J, Ito M, Nose M, Tashiro A, Hongo M, Oki Y, Nagura H, Sasano H (2000) Urocortin and corticotropin-releasing factor receptor expression in the human colonic mucosa. Peptides 21: 1799-1809.

93. Petraglia F, Florio P, Gallo R, Simoncini T, Saviozzi M, Di Blasio AM, Vaughan J, Vale W (1996) Human placenta and fetal membranes express human urocortin mRNA and peptide. J Clin Endocrinol Metab 81: 3807-3810.

94. Muramatsu Y, Sugino N, Suzuki T, Totsune K, Takahashi K, Tashiro A, Hongo M, Oki Y, Sasano H (2001) Urocortin and corticotropin-releasing factor receptor expression in normal cycling human ovaries. J Clin Endocrinol Metab 86: 1362-1369.

95. Florio P, Arcuri F, Ciarmela P, Runci Y, Romagnoli R, Cintorino M, Di Blasio AM, Petraglia F (2002) Identification of urocortin mRNA and peptide in the human endometrium. J Endocrinol 173: R9-14.

96. Uzuki M, Sasano H, Muramatsu Y, Totsune K, Takahashi K, Oki Y, Iino K, Sawai T (2001) Urocortin in the synovial tissue of patients with rheumatoid arthritis. Clin Sci (Lond) 100: 577-589.

97. Bamberger CM, Wald M, Bamberger AM, Ergun S, Beil FU, Schulte HM (1998) Human lymphocytes produce urocortin, but not corticotropin-releasing hormone. J Clin Endocrinol Metab 83: 708-711.

98. Chen R, Lewis KA, Perrin MH, Vale WW (1993) Expression cloning of a human corticotropin-releasing- factor receptor. Proc Natl Acad Sci USA 90: 89678971.

99. Lovenberg TW, Liaw CW, Grigoriadis DE, Clevenger W, Chalmers DT, De Souza EB, Oltersdorf T (1995) Cloning and characterization of a functionally distinct corticotropin-releasing factor receptor subtype from rat brain. Proc Natl Acad Sci USA 92: 836-840.

100. Timpl P, Spanagel R, Sillaber I, Kresse A, Reul JM, Stalla GK, Blanquet V, Steckler T, Holsboer F, Wurst W (1998) Impaired stress response and reduced anxiety in mice lacking a functional corticotropin-releasing hormone receptor 1. Nat Genet 19: 162-166.

101. Coste SC, Kesterson RA, Heldwein KA, Stevens SL, Heard AD, Hollis JH, Murray SE, Hill JK, Pantely GA, Hohimer AR, Hatton DC, Phillips TJ, Finn DA, Low MJ, Rittenberg MB, Stenzel P, Stenzel-Poore MP (2000) Abnormal adaptations to stress and impaired cardiovascular function in mice lacking corticotropinreleasing hormone receptor-2. Nat Genet 24: 403-409.

102. Bale TL, Contarino A, Smith GW, Chan R, Gold LH, Sawchenko PE, Koob GF, Vale WW, Lee KF (2000) Mice deficient for corticotropin-releasing hormone receptor-2 display anxiety-like behaviour and are hypersensitive to stress. Nat Genet 24: 410-414.

103. Kishimoto T, Radulovic J, Radulovic M, Lin CR, Schrick C, Hooshmand F, Hermanson O, Rosenfeld MG, Spiess J (2000) Deletion of crhr2 reveals an anxiolytic role for corticotropin-releasing hormone receptor2. Nat Genet 24: 415-419.

104. Parkes DG, Vaughan J, Rivier J, Vale W, May CN (1997) Cardiac inotropic actions of urocortin in conscious sheep. Am J Physiol 272: H2115-2122.

105. Parkes DG, Weisinger RS, May CN (2001) Cardiovascular actions of $\mathrm{CRH}$ and urocortin: an update. Peptides 22: 821-827. Review.

106. Terui K, Higashiyama A, Horiba N, Furukawa KI, Motomura S, Suda T (2001) Coronary vasodilation and positive inotropism by urocortin in the isolated rat heart. J Endocrinol 169: 177-183.

107. Okosi A, Brar BK, Chan M, D’Souza L, Smith E, Stephanou A, Latchman DS, Chowdrey HS, Knight RA (1998) Expression and protective effects of urocortin in cardiac myocytes. Neuropeptides 32: 167-171.

108. Brar BK, Stephanou A, Okosi A, Lawrence KM, Knight RA, Marber MS, Latchman DS (1999) CRHlike peptides protect cardiac myocytes from lethal ischaemic injury. Mol Cell Endocrinol 158: 55-63.

109. Brar BK, Jonassen AK, Stephanou A, Santilli G, Railson J, Knight RA, Yellon DM, Latchman DS (2000) Urocortin protects against ischemic and reperfusion injury via a MAPK-dependent pathway. $J$ Biol Chem 275: 8508-8514.

110. Brar BK, Stephanou A, Knight R, Latchman DS (2002) Activation of protein kinase $\mathrm{B} / \mathrm{Akt}$ by urocortin is essential for its ability to protect cardiac cells against hypoxia/reoxygenation-induced cell death. J Mol Cell 
Cardiol 34: 483-492.

111. Lawrence KM, Chanalaris A, Scarabelli T, Hubank M, Pasini E, Townsend PA, Comini L, Ferrari R, Tinker A, Stephanou A, Knight RA, Latchman DS (2002) K (ATP) channel gene expression is induced by urocortin and mediates its cardioprotective effect. Circulation 106: 1556-1562.

112. Schulman D, Latchman DS, Yellon DM (2002) Urocortin protects the heart from reperfusion injury via upregulation of p42/p44 MAPK signaling pathway. Am J Physiol Heart Circ Physiol 283: H1481-1488.

113. Scarabelli TM, Pasini E, Stephanou A, Comini L, Curello S, Raddino R, Ferrari R, Knight R, Latchman DS (2002) Urocortin promotes hemodynamic and bioenergetic recovery and improves cell survival in the isolated rat heart exposed to ischemia/reperfusion. J Am Coll Cardiol 40: 155-161.

114. Ikeda K, Tojo K, Sato S, Ebisawa T, Tokudome G, Hosoya T, Harada M, Nakagawa O, Nakao K (1998) Urocortin, a newly identified corticotropin-releasing factor-related mammalian peptide, stimulates atrial natriuretic peptide and brain natriuretic peptide secretions from neonatal rat cardiomyocytes. Biochem Biophys Res Comm 250: 298-304.

115. Heldwein KA, Redick DL, Rittenberg MB, Claycomb WC, Stenzel-Poore MP (1996) Corticotropin-releasing hormone receptor expression and functional coupling in neonatal cardiac myocytes and AT-1 cells. Endocrinology 137: 3631-3639.

116. Samson WK (1996) "Here the heart may give a useful lesson to the head". Endocrinology 137: 3629-3630.

117. Kimura Y, Takahashi K, Totsune K, Muramatsu Y, Kaneko C, Darnel AD, Suzuki T, Ebina M, Nukiwa T, Sasano H (2002) Expression of urocortin and corticotropin-releasing factor receptor subtypes in the human heart. J Clin Endocrinol Metab 87: 340-346.

118. Nishikimi T, Miyata A, Horio T, Yoshihara F, Nagaya N, Takishita S, Yutani C, Matsuo H, Matsuoka H, Kangawa K (2000) Urocortin, a member of the corticotropin-releasing factor family, in normal and diseased heart. Am J Physiol Heart Circ Physiol 279: H3031-3039.

119. Rademaker MT, Charles CJ, Espiner EA, Fisher S, Frampton CM, Kirkpatrick CM, Lainchbury JG, Nicholls MG, Richards AM, Vale WW (2002) Beneficial hemodynamic, endocrine, and renal effects of urocortin in experimental heart failure: comparison with normal sheep. J Am Coll Cardiol 40: 1495-1505.

120. Baigent SM (2001) Peripheral corticotropin-releasing hormone and urocortin in the control of the immune response. Peptides 22: 809-820. Review.

121. Kageyama K, Bradbury MJ, Zhao L, Blount AL, Vale WW (1999) Urocortin messenger ribonucleic acid: tissue distribution in the rat and regulation in thymus by lipopolysaccharide and glucocorticoids. Endocrinology 140: 5651-5658.
122. Chatzaki E, Charalampopoulos I, Leontidis C, Mouzas IA, Tzardi M, Tsatsanis C, Margioris AN, Gravanis A (2003) Urocortin in human gastric mucosa: relationship to inflammatory activity. J Clin Endocrinol Metab 88: 478-483.

123. Oki Y, Iwabuchi M, Masuzawa M, Watanabe F, Ozawa M, Iino K, Tominaga T, Yoshimi T (1998) Distribution and concentration of urocortin, and effect of adrenalectomy on its content in rat hypothalamus. Life Sci 62 : 807-812.

124. Poliak S, Mor F, Conlon P, Wong T, Ling N, Rivier J, Vale W, Steinman L (1997) Stress and autoimmunity: the neuropeptides corticotropin-releasing factor and urocortin suppress encephalomyelitis via effects on both the hypothalamic-pituitary-adrenal axis and the immune system. J Immunol 158: 5751-5756.

125. Okamoto S, Ishikawa I, Kimura K, Saito M (1998) Potent suppressive effects of urocortin on splenic lymphocyte activity in rats. Neuroreport 9: 4035-4039.

126. Singh LK, Boucher W, Pang X, Letourneau R, Seretakis D, Green M, Theoharides TC (1999) Potent mast cell degranulation and vascular permeability triggered by urocortin through activation of corticotropinreleasing hormone receptors. J Pharmacol Exp Ther 288: 1349-1356.

127. Wang X, Su H, Copenhagen LD, Vaishnav S, Pieri F, Shope CD, Brownell WE, De Biasi M, Paylor R, Bradley A (2002) Urocortin-deficient mice display normal stress-induced anxiety behavior and autonomic control but an impaired acoustic startle response. Mol Cell Biol 22: 6605-6610.

128. Vetter DE, Li C, Zhao L, Contarino A, Liberman MC, Smith GW, Marchuk Y, Koob GF, Heinemann SF, Vale W, Lee KF (2002) Urocortin-deficient mice show hearing impairment and increased anxiety-like behavior. Nat Genet 31: 363-369.

129. Reyes TM, Lewis K, Perrin MH, Kunitake KS, Vaughan J, Arias CA, Hogenesch JB, Gulyas J, Rivier J, Vale WW, Sawchenko PE (2001) Urocortin II: a member of the corticotropin-releasing factor (CRF) neuropeptide family that is selectively bound by type $2 \mathrm{CRF}$ receptors. Proc Natl Acad Sci USA 98: 2843-2848.

130. Hsu SY, Hsueh AJ (2001) Human stresscopin and stresscopin-related peptide are selective ligands for the type 2 corticotropin-releasing hormone receptor. Nat Med 7: 605-611.

131. Lewis K, Li C, Perrin MH, Blount A, Kunitake K, Donaldson C, Vaughan J, Reyes TM, Gulyas J, Fischer W, Bilezikjian L, Rivier J, Sawchenko PE, Vale WW (2001) Identification of urocortin III, an additional member of the corticotropin-releasing factor (CRF) family with high affinity for the CRF2 receptor. Proc Natl Acad Sci USA 98: 7570-7575.

132. Dautzenberg FM, Hauger RL (2002) The CRF peptide family and their receptors: yet more partners discovered. Trends Pharmacol Sci 23: 71-77. Review. 
133. Li C, Vaughan J, Sawchenko PE, Vale WW (2002) Urocortin III-immunoreactive projections in rat brain: partial overlap with sites of type 2 corticotrophinreleasing factor receptor expression. J Neurosci 22: 991-1001.

134. Berlind A (1972) Teleost caudal neurosecretory system: release of urotensin II from isolated urophyses. Gen Comp Endocrinol 18: 557-560.

135. MacLean MR, Alexander D, Stirrat A, Gallagher M, Douglas SA, Ohlstein EH, Morecroft I, Polland K (2000) Contractile responses to human urotensin-II in rat and human pulmonary arteries: effect of endothelial factors and chronic hypoxia in the rat. Br J Pharmacol 130: 201-204.

136. Bottrill FE, Douglas SA, Hiley CR, White R (2000) Human urotensin-II is an endothelium-dependent vasodilator in rat small arteries. Br J Pharmacol 130: 1865-1870.

137. Stirrat A, Gallagher M, Douglas SA, Ohlstein EH, Berry C, Kirk A, Richardson M, MacLean MR (2001) Potent vasodilator responses to human urotensin-II in human pulmonary and abdominal resistance arteries. $\mathrm{Am} \mathrm{J}$ Physiol Heart Circ Physiol 280: H925-928.

138. Russell FD, Molenaar P, O'Brien DM (2001) Cardiostimulant effects of urotensin-II in human heart in vitro. Br J Pharmacol 132: 5-9.

139. Watanabe T, Pakala R, Katagiri T, Benedict CR (2001) Synergistic effect of urotensin II with mildly oxidized LDL on DNA synthesis in vascular smooth muscle cells. Circulation 104: 16-18.

140. Watanabe T, Pakala R, Katagiri T, Benedict CR (2001) Synergistic effect of urotensin II with serotonin on vascular smooth muscle cell proliferation. J Hypertens 19: 2191-2196.

141. Sauzeau V, Le Mellionnec E, Bertoglio J, Scalbert E, Pacaud P, Loirand G (2001) Human urotensin IIinduced contraction and arterial smooth muscle cell proliferation are mediated by RhoA and Rho-kinase. Circ Res 88: 1102-1104.

142. Zou Y, Nagai R, Yamazaki T (2001) Urotensin II induces hypertrophic responses in cultured cardiomyocytes from neonatal rats. FEBS Lett 508: 57-60.

143. Silvestre RA, Rodriguez-Gallardo J, Egido EM, Marco J (2001) Inhibition of insulin release by urotensin II-a study on the perfused rat pancreas. Horm Metab Res 33: 379-381.

144. Totsune K, Takahashi K, Arihara Z, Sone M, Satoh F, Ito S, Kimura Y, Sasano H, Murakami O (2001) Role of urotensin II in patients on dialysis. Lancet 358: 810 811.

145. Matsushita M, Shichiri M, Imai T, Iwashina M, Tanaka H, Takasu N, Hirata Y (2001) Co-expression of urotensin II and its receptor (GPR14) in human cardiovascular and renal tissues. J Hypertens 19: 2185-2190.

146. Shenouda A, Douglas SA, Ohlstein EH, Giaid A (2002) Localization of urotensin-II immunoreactivity in normal human kidneys and renal carcinoma. $J$ Histochem Cytochem 50: 885-889.

147. Richards AM, Nicholls MG, Lainchbury JG, Fisher S, Yandle TG (2002) Plasma urotensin II in heart failure. Lancet 360: 545-546.

148. Ng LL, Loke I, O'Brien RJ, Squire IB, Davies JE (2002) Plasma urotensin in human systolic heart failure. Circulation 106: 2877-2880.

149. Heller J, Schepke M, Neef M, Woitas R, Rabe C, Sauerbruch T (2002) Increased urotensin II plasma levels in patients with cirrhosis and portal hypertension. J Hepatol 37: 767-772.

150. Totsune K, Takahashi K, Arihara Z, Sone M, Ito S, Murakami O (2003) Increased plasma urotensin II levels in patients with diabetes mellitus. Clin Sci (Lond) 104: 1-5.

151. Douglas SA, Tayara L, Ohlstein EH, Halawa N, Giaid A (2002) Congestive heart failure and expression of myocardial urotensin II. Lancet 359: 1990-1997.

152. Zhu F, Ji L, Luo B (2002) The role of urotensin II gene in the genetic susceptibility to type 2 diabetes in Chinese population. Zhonghua Yi Xue Za Zhi 82: 1473-1475.

153. Wenyi Z, Suzuki S, Hirai M, Hinokio Y, Tanizawa Y, Matsutani A, Satoh J, Oka Y (2003) Role of urotensin II gene in genetic susceptibility to type 2 diabetes mellitus in Japanese subjects. Diabetologia 46: 972-976.

154. Dschietzig T, Bartsch C, Pregla R, Zurbrugg HR, Armbruster FP, Richter C, Laule M, Romeyke E, Neubert C, Voelter W, Baumann G, Stangl K (2002) Plasma levels and cardiovascular gene expression of urotensin-II in human heart failure. Regul Pept 110: 33-38.

155. Takahashi K, Totsune K, Murakami O, Shibahara S (2001) Expression of urotensin II and urotensin II receptor mRNAs in various human tumor cell lines and secretion of urotensin II-like immunoreactivity by SW-13 adrenocortical carcinoma cells. Peptides 22: 1175-1179.

156. Takahashi K, Totsune K, Murakami O (2001) Expression of three vasoactive peptides, urotensin-II, adrenomedullin and endothelin-1, in a human renal cell carcinoma cell line, VMRC-RCW. Clin Exp Nephrol 5: 246-249.

157. Takahashi K, Totsune K, Murakami O, Arihara Z, Noshiro T, Hayashi Y, S Shibahara S (2003) Expression of urotensin II and its receptor in adrenal tumors and stimulation of proliferation of cultured tumor cells by urotensin II. Peptides 24: 301-306.

158. Ziltener P, Mueller C, Haenig B, Scherz MW, Nayler O (2002) Urotensin II mediates ERK1/2 phosphorylation and proliferation in GPR14-transfected cell lines. J Recept Signal Transduct Res 22: 155-168.

159. Conlon JM (2000) Singular contributions of fish neuroendocrinology to mammalian regulatory peptide research. Regul Pept 93: 3-12. Review. 